\title{
Weather Note
}

\section{TRAIN DERAILMENTS BY TORNADOES}

\author{
WILLIAM E. HARDY
}

U.S. Weather Bureau, Washington, D.C.

At about 1940 CsT on June 11, 1964, a 16-car Missouri Pacific freight train was moving slowly westward between Claflin and Hoisington in central Kansas when it was struck from the north by a tornado with path width of 150 yards. According to newspaper and climatological reports eight hopper-type cars near the rear of the train were derailed by the twister, only the caboose remaining on the tracks. The locomotive and forward eight cars of the train proceeded to Hoisington. The accompanying photograph (fig. 1) shows two of the derailed cars.
Considering the overall number of tornadoes reported each year it is a rare occurrence, but not without precedent, when a tornado encounters a moving train. According to available reports [1] the Great Northern Railway has had passenger trains and a freight struck by tornadoes in Minnesota on several occasions.

The "Great Northern Limited" was traveling at 30-40 m.p.h. on June 22, 1919 when the Fergus Falls, Minn. tornado struck the baggage car immediately behind the tender blowing it from the tracks and depositing it about

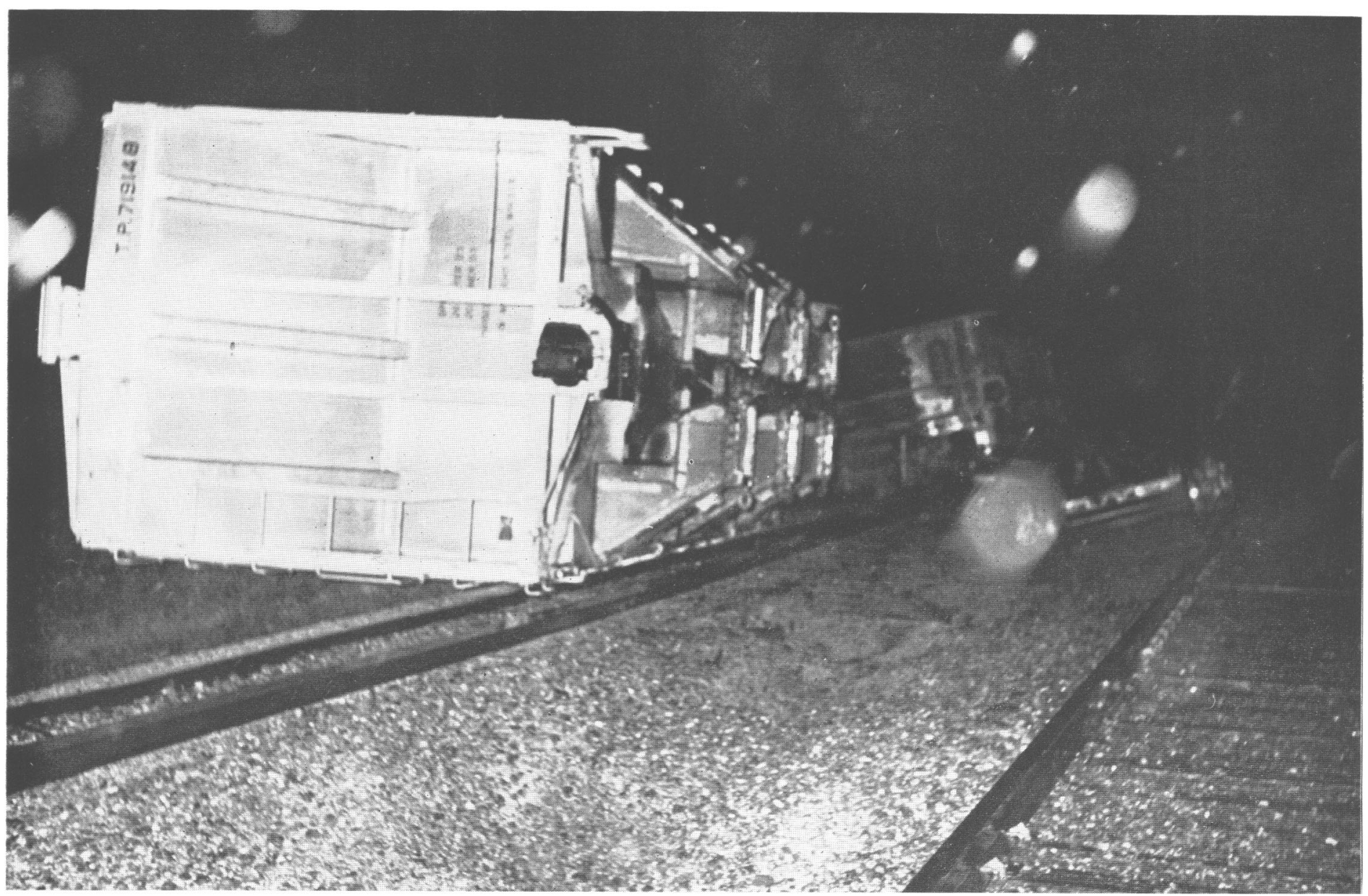

Figune 1.-Nighttime flash photograph showing two of the eight cars of a Missouri Pacific freight train derailed by a tornado near Claflin, Kins. on June 11, 1964. Photo by Tom VanBrimmer, Great Bend, Kans. 


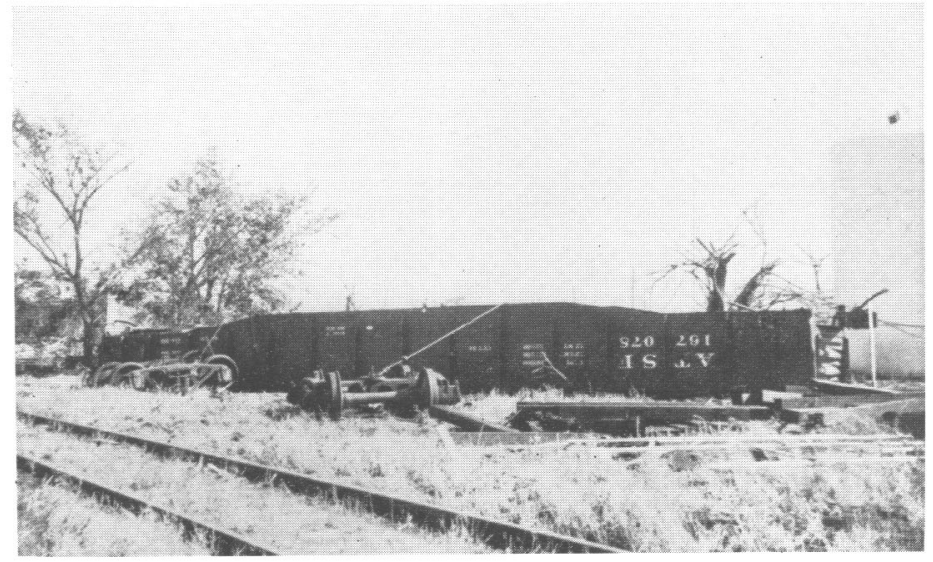

Figure 2.- Steel gondola blown from tracks by the Udall, Kans. tornado of May 25, 1955. Photo by Melvin Haynes.

$30 \mathrm{ft}$. from the road bed and at right angles. As a consequence, 7 of the 11 coaches following were derailed. Again, on May 27, 1931 at Moorhead, Minn., an 83-ton coach of the speeding "Empire Builder" was lifted from the tracks and carried through the air by a tornado which struck at right angles. It was deposited in a ditch $80 \mathrm{ft}$. from the road bed while other coaches of the train were torn from the locomotive and derailed. One passenger was hurled through a window and crushed in the wreckage. Minnesota again was featured when on September 4, 1941, loaded steel coal cars weighing $80,000 \mathrm{lb}$. each were overturned by a tornado near Minneapolis.

Of an 82-car freight train at Gage, Okla. on June 21, 1958,17 cars were derailed and $180 \mathrm{ft}$. of track was torn up as a tornado crossed the right-of-way.
However, there are relatively numerous instances of standing freight cars and steel gondolas being blown off the tracks by tornadoes, several such cases occurring during the passage of the Dallas, Tex., tornado of April 2, 1957 [2]. Engineering computations showed that the minimum tornado wind speeds required varied from 83 m.p.h. to 217 m.p.h., depending on the type of car, its weight, and the angle at which it was struck by the winds. Figure 2 shows a steel gondola which the Udall, Kans., tornado of May 25, 1955, lifted from the tracks (and trucks) and deposited upside down about $50 \mathrm{ft}$. away.

It is possible to indicate the extent to which the odds are against such occurrences. Thom [3] has developed an equation for determining the mean probability of a tornado's striking a point in any $1^{\circ}$ square in the United States, the mean area of a tornado path being computed as $2.8209 \mathrm{mi}^{2}$ For the $1^{\circ}$ square (approximately 3,735 mi. $^{2}$ in area) in which the freight west of Claflin, Kans., was struck, the mean recurrence interval is once in 474 $\mathrm{yr} .$, and for the strikes in Minnesota once in 1,486 yr.

\section{REFERENCES}

1. L. V. Walford, "Tornado Occurrences in the United States," Technical Paper No. 20, U.S. Weather Bureau, Washington, D.C., Revised 1960, $71 \mathrm{pp}$.

2. W. H. Hoecker, Jr. et al., "The Tornadoes at Dallas, Tex., April 2, 1957," Research Paper No. 41, U.S. Weather Bureau, Washington, D.C., 1960, 175 pp.

3. H. C. S. Thom, "Tornado Probabilities," Monthly Weather Review, vol. 91, Nos. 10-12, Oct.-Dec. 1963, pp. 730-736.

[Received August 5, 1964] 